\title{
Mineral assemblages \\ as a record of the evolutionary \\ history of the Pepper Mts. Shale Formation (the Holy Cross Mts.)
}

\author{
Beata Naglik, Lucyna Natkaniec-Nowak, Wiesław Heflik \\ AGH University of Science and Technology, Faculty of Geology, Geophysics and Environmental Engineering; \\ al. A. Mickiewicza 30,30-059 Krakow, Poland; e-mail:beata.naglik@op.pl
}

\begin{abstract}
(C) 2016 Authors. This is an open access publication, which can be used, distributed and reproduced in any medium according
\end{abstract} to the Creative Commons CC-BY 4.0 License requiring that the original work has been properly cited.

Received: 31 March 2016; accepted: 1 June 2016

\begin{abstract}
The Pepper Mts. Shale Formation, consisting of: clayey shales, mudstones and sandstones, as one of the oldest unit of the Holy Cross Mts., was subjected to mineralogical and petrographical studies. In order to reconstruct the geological history of the succession, mineral assemblages were characterized from the genetic point of view. Pyrite and goethite taking a form of bacterial-cell pseudomorphoses, crystallized during sedimentation and/or diagenesis, while quartz, kaolinite, goethite and chlorite prove subsequent alteration due to the hydrothermal fluid circulation. Secondary sulphates occurring on the pyrite-bearing rock outcrops mark the way of weathering processes. According to the presented results, Cambrian sediments were affected by hot fluids, which caused mineral recomposition and maturing of organic matter. Under the hypergenic conditions sulphate crust precipitate with pickeringite $\left[\mathrm{MgAl}_{2}\left(\mathrm{SO}_{4}\right)_{4} \cdot 22 \mathrm{H}_{2} \mathrm{O}\right]$, as a dominant phase accompanied by alunogen $\left[\mathrm{Al}_{2}\left(\mathrm{SO}_{4}\right)_{3} \cdot 17 \mathrm{H}_{2} \mathrm{O}\right]$ and small amount of epsomite $\left[\mathrm{MgSO}_{4} \cdot 7 \mathrm{H}_{2} \mathrm{O}\right]$.
\end{abstract}

Keywords: the Pepper Mts., Łysogóry unit, bacterial-cell pseudomorphoses, hydrothermal fluid circulation, chemical weathering

\section{INTRODUCTION}

This paper summarizes the mineralogical and petrographical investigations of clastic rocks from the Pepper Mts. (the Holy Cross Mts.) carried out by the authors over the course of several years. A new approach to the genetic problems of the formation was presented by describing the mineralogical associations connected with particular stages of the succession's evolution history. This paper is a compilation of previously published data (Naglik et al. 2015, 2016) and new results.

\section{Study area location}

The Pepper Mts. are located in the central part of Poland, within the administrative boundary of the city of Sandomierz. They constitute the peripheral part of the Holy Cross Mts. (Fig. 1), representing a geological structure exposed in a topographic scarp of $40 \mathrm{~m}$ height cut by deep gorges. The landscape of the Pepper Mts. is shaped by numerous landslides and erosion channels. Physical and chemical weathering is intensified by the southern exposure of the slopes and scarce vegetation. Due to those processes, cover of a pepper-like color and structure is forming. 

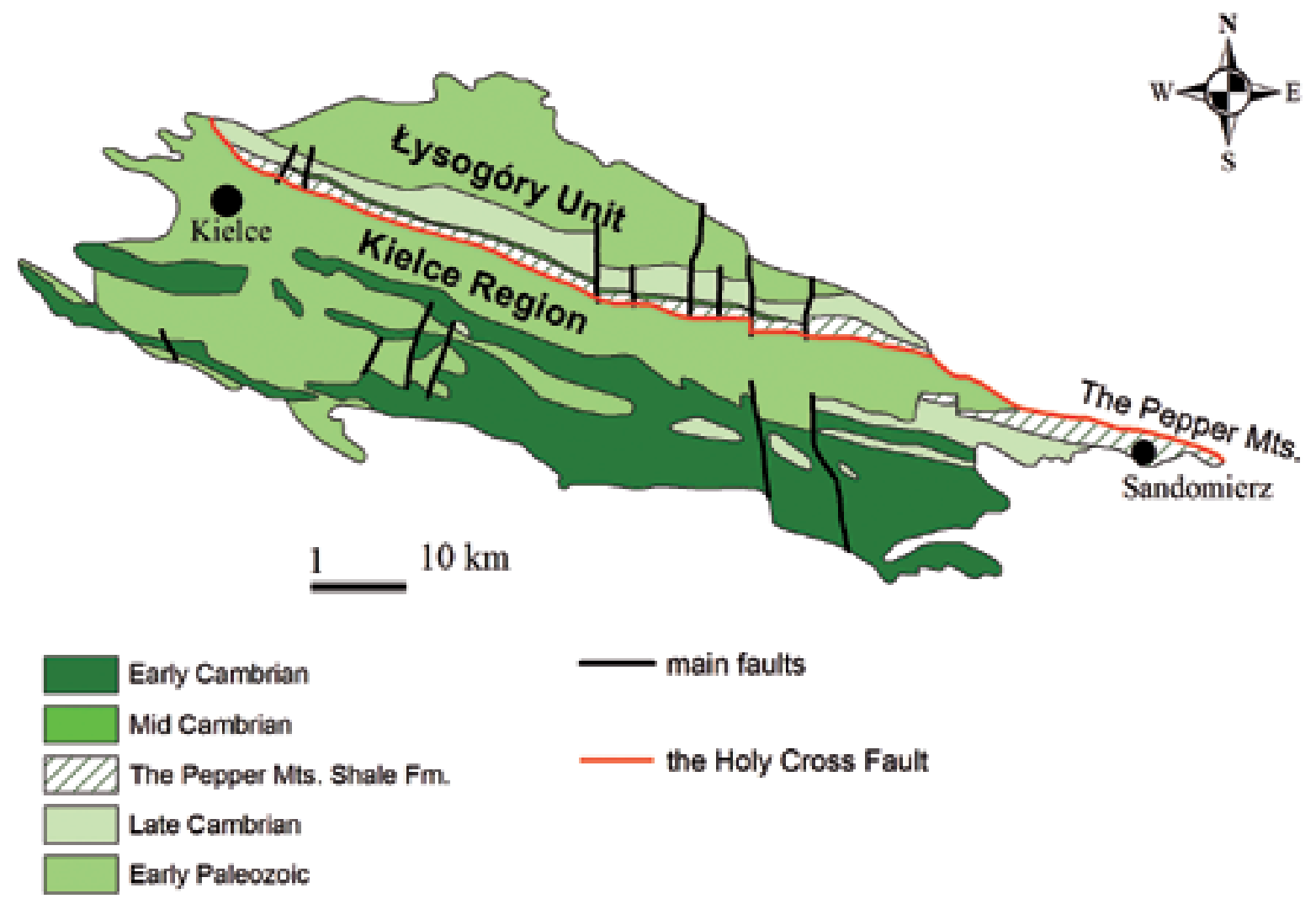

- main faults

the Holy Cross Fault

Fig. 1. Position of the Pepper Mts. against the backdrop of the main tectonic units of the Holy Cross Mts. on the basis of Orłowski (1975), changed

\section{Geologic framework}

The Pepper Mts. are stratotype area for one of the oldest units of the Holy Cross Mts., named according to Orłowski (1975) as the Pepper Mts. Shale Formation (PMSF). Stratigraphic correlation of the studied succession is questionable as the scarcity of fossils and complicated tectonic layout made the dating difficult. There is no agreement as to whether all of the litostratigraphic subdivisions of even $700 \mathrm{~m}$ thick formation can represent the same Middle Cambrian age (Michniak 1969, Kowalczewski 1995, Szczepanik 1997). Due to the new microfossils findings (Bąk et al. 2015) the age of the formation should be extended to the lower Middle Cambrian.

Geological studies of the PMSF have been carried out for more than 150 years. Push (1833) was the first who mentioned the Pepper Mts. in a published work. From that time most works were devoted to the stratigraphic correlations (Zejszner 1869, Tietze 1883a, 1883b, Siemiradzki 1886,
1887, Gürich 1892a, 1892b, 1899-1901, Samsonowicz 1916, 1920, Orłowski 1964, Kowalczewski 1995) or sedimentological problems (Przewłocki 2000, Malec 2006, Jaworowski \& Sikorska 2010). Much less frequently were tectonic studies undertaken (Żak 1962, Mastella \& Mizerski 1981) possibly as a result of the complicated layout of the Pepper Mts. Also mineralogical and petrographical analysis has been carried out relatively rarely (Kuhl 1931, Michniak 1969, Przewłocki 2000, Salwa 2006).

\section{MATERIALS AND METHODS}

Studied samples of clayey shales, mudstones and sandstones were collected during fieldwork carried out in the years 2014-2015. 30 samples were collected from outcrops mainly located within the western part of the succession along to the Vistula River channel (Fig. 2). 


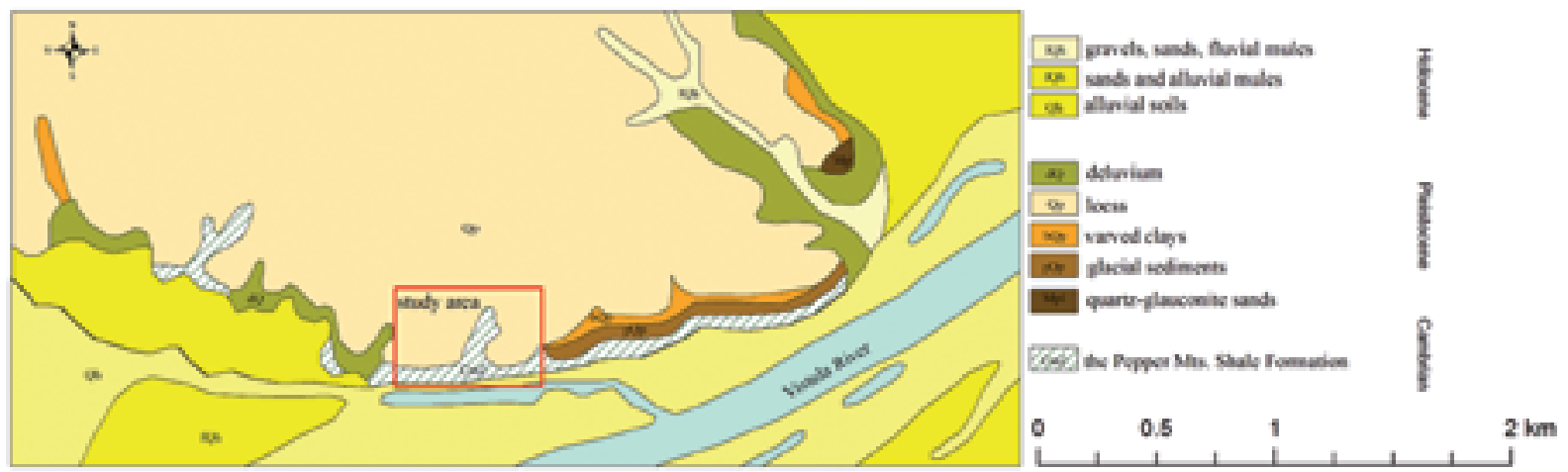

Fig. 2. Detailed geological map of the Pepper Mts. (with sampling area) on the basis of Bielecka (1964), changed

Sample preparation was adjusted to the methodological requirements. Special preparation was requested for the analysis of hydrated sulphates due to their high solubility in water. After adhering samples to the glass they were polished without using water. Mineralogical and petrographical investigations were provided by applying the following methods: optical observations, scanning electron microscopy (SEM), Raman microspectroscopy and electron microprobe (EPMA).

Optical observations were performed under transmitted light polarizing microscope JENALAB Carl Zeiss Jena, Olympus BX 51 working with DP12 Camera equipped with 4X, 10X, 40X and $60 \mathrm{X}$ magnification objectives. Analysis was conducted at the AGH University of Science and Technology, Faculty of Geology, Geophysics and Environmental Protection, Krakow, Poland.

Backscattered Electron (BSE) and Secondary Electron (SE) imaging was performed on thin sections and natural samples without previous preparation. Observations were provided using a FEI Quanta 200 FEF scanning electron microscope equipped with an Energy Dispersive Spectroscopy (EDS) Detector. The system was operated at $20 \mathrm{kV}$ accelerating voltage in low-vacuum mode. Analysis was provided at the AGH University of Science and Technology, Faculty of Geology, Geophysics and Environmental Protection, Krakow, Poland.

Raman spectra of minerals and carbonaceous material were recorded using a LabRAM-HR 800 (Horiba Jobin-Yvon), UV-VIS-NIR version spectrometer operating in confocal mode, fitted with Peltier cooled CCD detector Synnapse (Horiba Jobin-Yvon) and working with an Olympus BX-41 microscope equipped with 5X, 20X, 50X and 100X magnification objectives. The samples were excited by the $532.1 \mathrm{~nm}$ line of the Nd:YAG laser. Spectra of solid and fluid inclusions trapped within quartz crystals were collected with a 600 line $/ \mathrm{mm}$ grating in the spectral range of $60-4000 \mathrm{~cm}^{-1}$, in 2 accumulations.

Chemical composition of chlorites was quantitatively studied on a Field emmision electron microprobe JEOL JXA-8530F (Earth Science Institute of the Slovak Academy of Sciences, Banská Bystrica, Slovakia) at following condition: $15 \mathrm{kV}$, $20 \mathrm{nA}$, probe diameter $1-2 \mu \mathrm{m}$, counting time $10 \mathrm{~s}-$ peak and $5 \mathrm{~s}$ for bg, ZAF correction. Used standards: diopside (CaKa PETL, SiKa TAP), rhodonite (MnKa LIFL), albite (NaKa, AlKa TAP), olivine (MgKa TAP), rutile (TiKa PETH), hematite (FeKa, LIFH), orthoclase (KKa PETJ).

\section{RESULTS}

\section{Mineralogical and petrographical characteristic of rocks}

The PMSF consists of clayey shales associated with mudstones and sandstones (Naglik et al. 2016). The character of the dominant lithology changes in an eastwardly direction. In the west part of the succession, clayey shales prevail while mudstones (rarely sandstones) occur as thin interbeds. In turn, the eastern outcrops are dominated by sandstones, something which is particularly visible in the Kamien Łukawski old quarry. The mineral composition of all of the rock types from the succession is similar. Nonundulatory quartz as the main component is mostly terrigenous with sharp-edged habit (Naglik et al. 2016). Some quartz grains are surrounded by reaction zones. 
Quartz is accompanied by strongly altered micas which show traces of transformation into chlorite or kaolinite. A more diversified mineral composition is presented by mudstones in which the sericite, calcite and albite twinnings were observed. Heavy minerals are represented by goethite, zircon, rutile and anatase. Pyrite of both framboidal and euhedral habit was only observed in mudstones (Naglik et al. 2016).

The main compounds of the mineral composition of the rocks were divided into three genetic groups. Pyrite and goethite represents the sedimentary and/or diagenetic stage of the formation evolution history. Quartz, chlorite, kaolinite and calcite occurring as veins resulted from hydrothermal activity. Finally, the secondary sulphate minerals which precipitate under hypergenic conditions determine the manner of chemical weathering.

\section{Products of sedimentation/diagenesis}

Pyrite and goethite of framboidal and euhedral habit occur as a microbial cell pseudomorphoses (Fig. 3). Identification of those minerals based on the Raman spectra which show diagnostic bands: $434,383,348 \mathrm{~cm}^{-1}$ for pyrite and $675,546,394$, $295 \mathrm{~cm}^{-1}$ for goethite. Except for the characteristic bands of minerals, organic matter was also marked by the bands: $1000-1800 \mathrm{~cm}^{-1}$ and $2500-3100 \mathrm{~cm}^{-1}$.
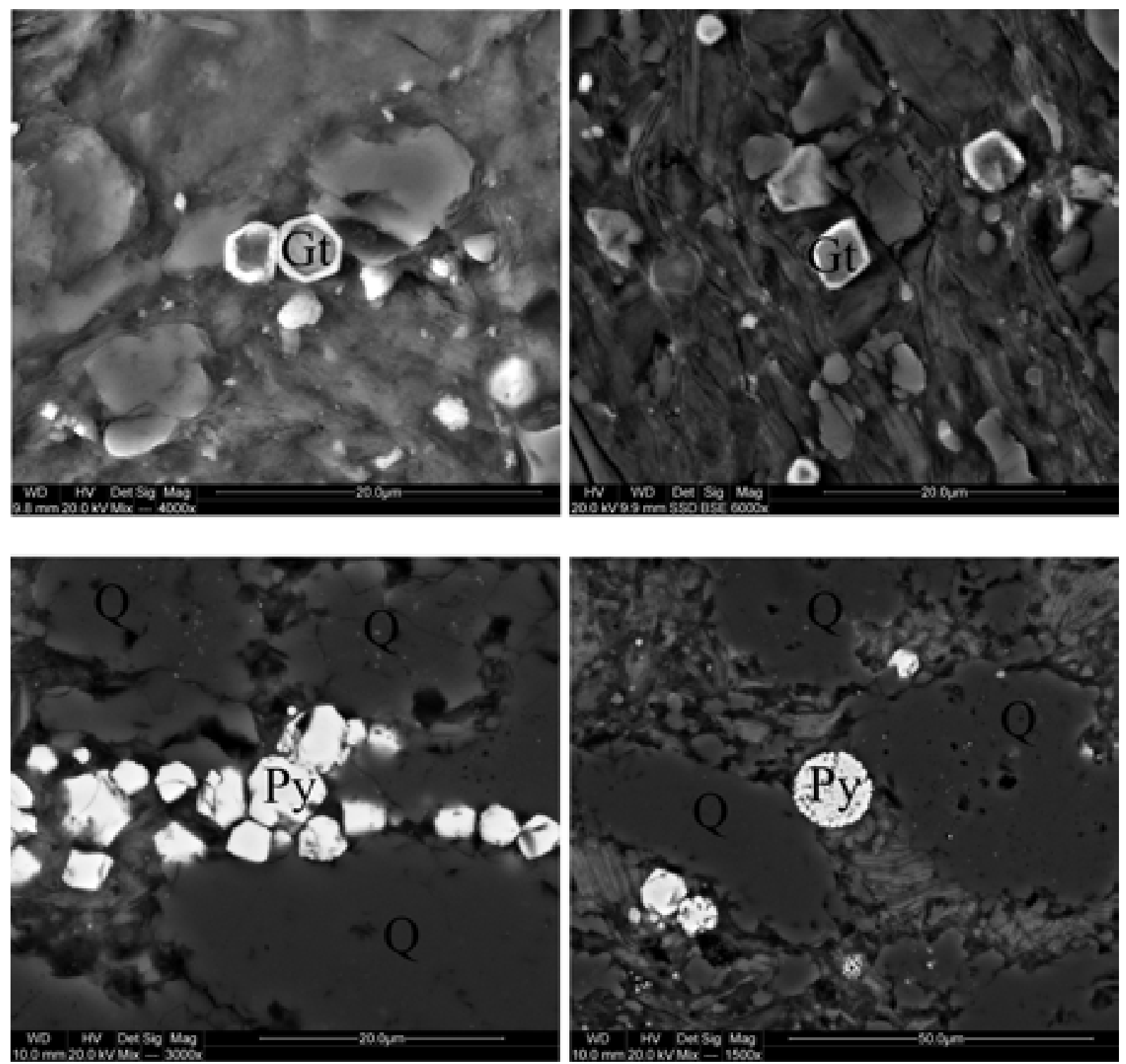

Fig. 3. SEM images of pyrite and goethite crystals (Naglik 2016) 
The relationship between intensity of specific bands and the place of laser focusing is very symptomatic for the further interpretations. The higher intensity of mineral bands as compared to those of organic matter is observed when the laser is focused on the framboids rim. On the other hand, the intensity of OM bands increases when the laser is focused on the central part of the analyzed form. This may imply the biological origin of both the pyrite and goethite (Fig. 4).

The time of biomineralization processes could be the subject of discussion. According to Przewłocki (2000), pyrite crystallized in the early diagenesis (both framboidal and euhedral forms) while iron hydroxides and oxides resulted from pyrite transformation during late diagenesis stage. Some genetic statements could be made on the basis of framboids diameter distribution. On the basis of pyrite size, specimens of syngenetic and diagenetic origin can be distinguished as it is believed that framboids with a diameter larger than $6 \mu \mathrm{m}$ cannot be formed in the water column. In the studied case, 75 framboids were measured. Framboids of size less than $6 \mu \mathrm{m}$ are dominant, forming $50 \%$ of the studied population but, nevertheless, larger ones were also observed. The size of some framboids even exceeded the value of $30 \mu \mathrm{m}$ and, therefore, the studied population is statistically inhomogeneous, as illustrated on the histogram (Fig. 5). The mean value is $7 \mu \mathrm{m}$ with a standard deviation of 17.45. According to Wilkin \& Barnes (1996), framboids of such average diameter should be considered as having been formed in the early stage of diagenesis. Much the same statement was assumed by Przewłocki (2000). Nevertheless, the mean value is overestimated due to the presence of individual bigger framboids. If taking into account the biological genesis of pyrite framboids it can be assumed that the size is mostly determined by the size of the replaced organic cell. Therefore the syngenetic origin of the pyrite and goethite as well cannot be rejected.

\section{Products of hydrothermal alteration}

Sediments from the PMSF underwent thermal alteration due to the hydrothermal fluid activity. The studied complex was previously interpreted as having been subjected to the advanced stages of diagenesis (Michniak 1969). Nevertheless, the petrographic evidence of rocks resulted from burial diagenesis are similar to those which were affected by migrating fluids (Środoń 1996).

Hot fluid activity is marked by the presence of veins filled with authigenic minerals. Clayey shales and mudstones are cut by veins built with quartz, kaolinite and Fe mineralization (goethite?). A tripartite zoning of veins could be observed: marginal parts are composed of euhedral quartz crystals of size larger than terrigenous quartz grains from surrounding rock mass, the central part of vein is built with kaolinite partly transformed into chlorite accompanied by Fe compound (Fig. 6). Some veins are monomineralic: filled with minerals from kaolinite group, quartz or goethite. Veins from sandstones represent different types as they are composed of calcite. The temperatures of the fluid discharge events were established on the basis of chlorite geothermometry and the Raman data of carbonaceous material (CM).

Tripartite veins representing the syntaxial type, and therefore the oldest episode of fluid discharge, resulted in quartz crystallization. The studied specimens of quartz bear a lot amount of primary and secondary inclusions consisting mostly of methane, nitrogen and carbon dioxide. The temperature of quartz crystallization obtained on the basis of CM inclusions can reach even ca. $300^{\circ} \mathrm{C}$ (Naglik et al. 2015).

The kaolinite of hydrothermal origin crystalized subsequently from the fluids saturated in respect to $\mathrm{Al}^{3+}$. The temperatures of the younger episode of fluids migration is difficult to estimate as kaolinite could crystalize under hypergenic conditions but is also stable in the greenschist metamorphic zone. Hydrothermal genesis of the studied kaolinite could be proven by high crystallinity of this mineral documented on the basis of Raman microspectroscopic study. The identification of highly-crystalline type of kaolinite could be marked by diagnostic bands: 790, 731, 460, 431, 331, 263, 239 and $130 \mathrm{~cm}^{-1}$ (Fig. 7).

Subsequent hot fluids activity caused the crystallization of Fe-minerals. As a result also the chlorite was formed due to the kaolinite and micas transformation. The temperatures of this event were determined on the basis of chlorite goethermometer proposed by Bourdelle et al. (2013). 

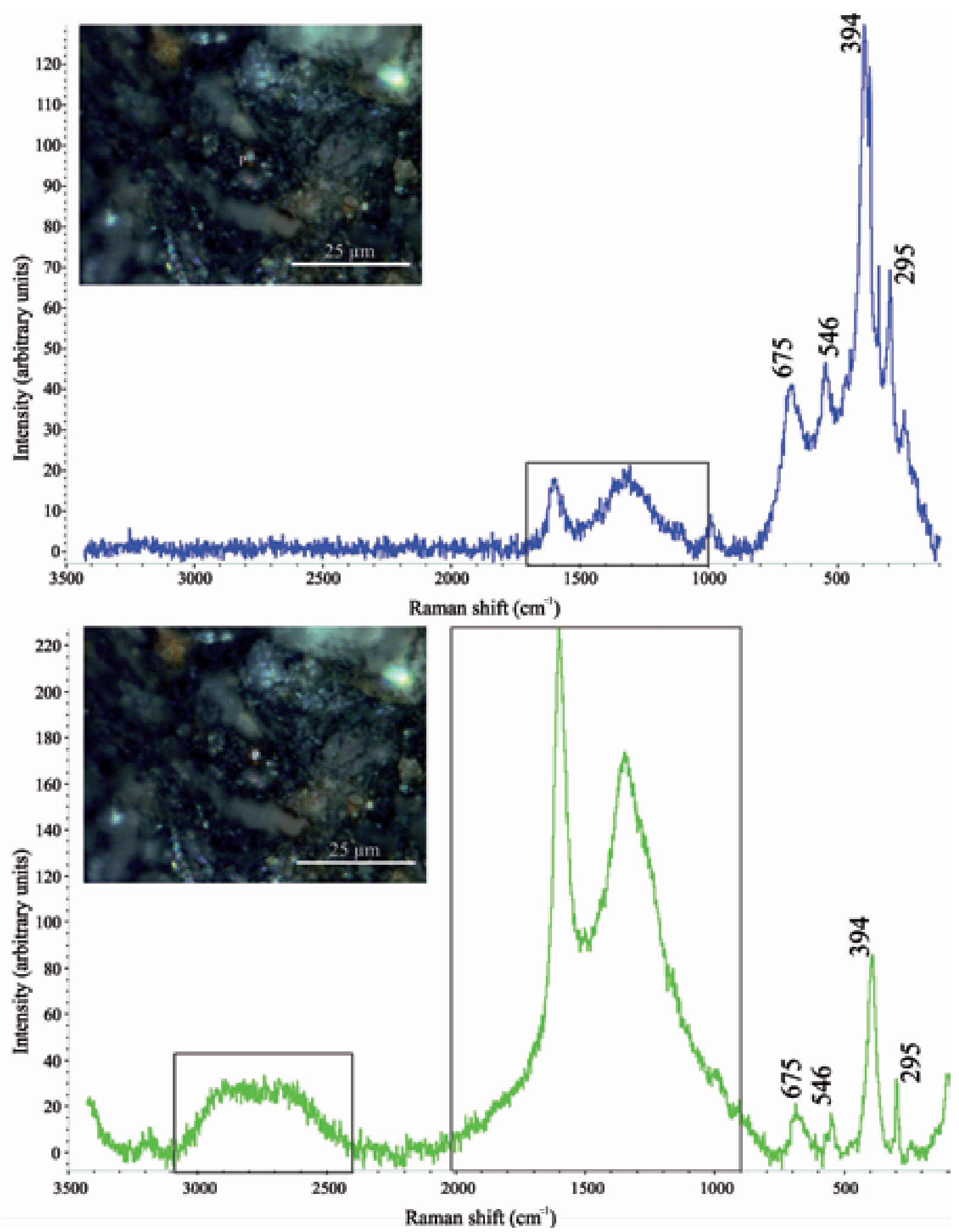

Fig. 4. Raman spectra of pyrite and associated carbonaceous material: P - laser focusing point (Naglik 2016) 


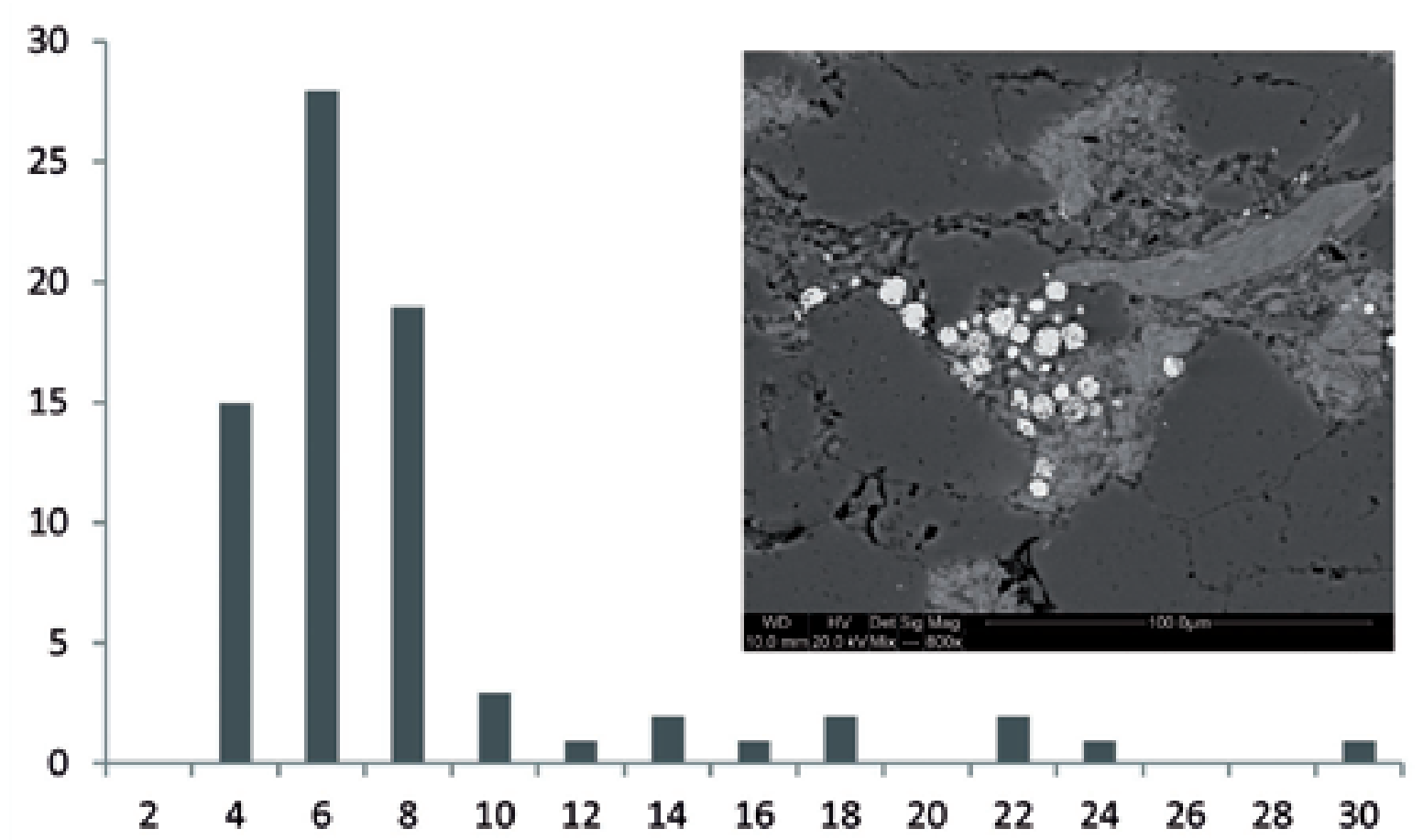

Fig. 5. Histogram of the distribution of pyrite framboid diameters (Naglik 2016)

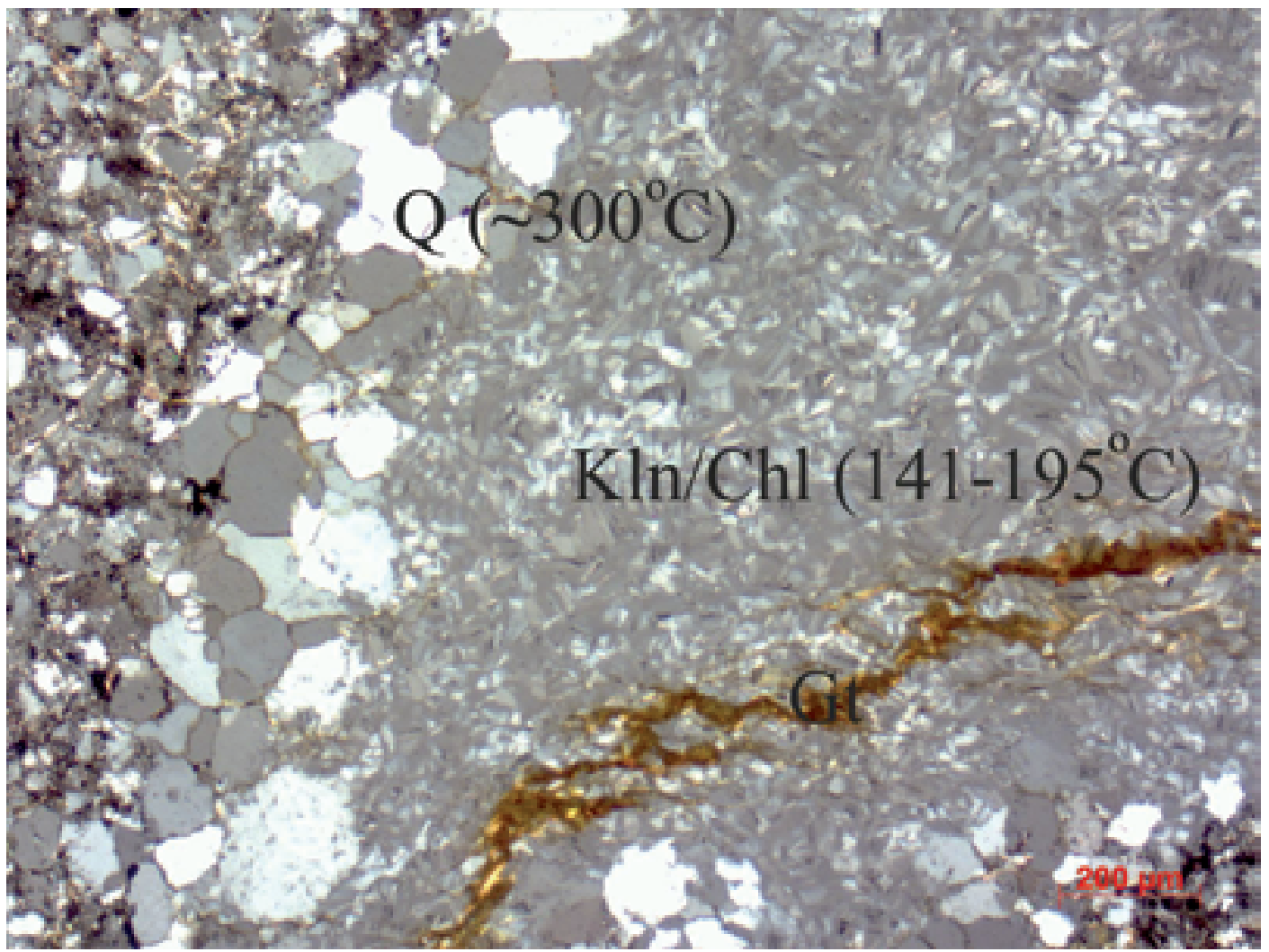

Fig. 6. Tripartite vein from mudstone: $Q$ - quartz, Chl - chlorite, Gt - goethite. In brackets, the probable temperatures of mineral formations are marked 


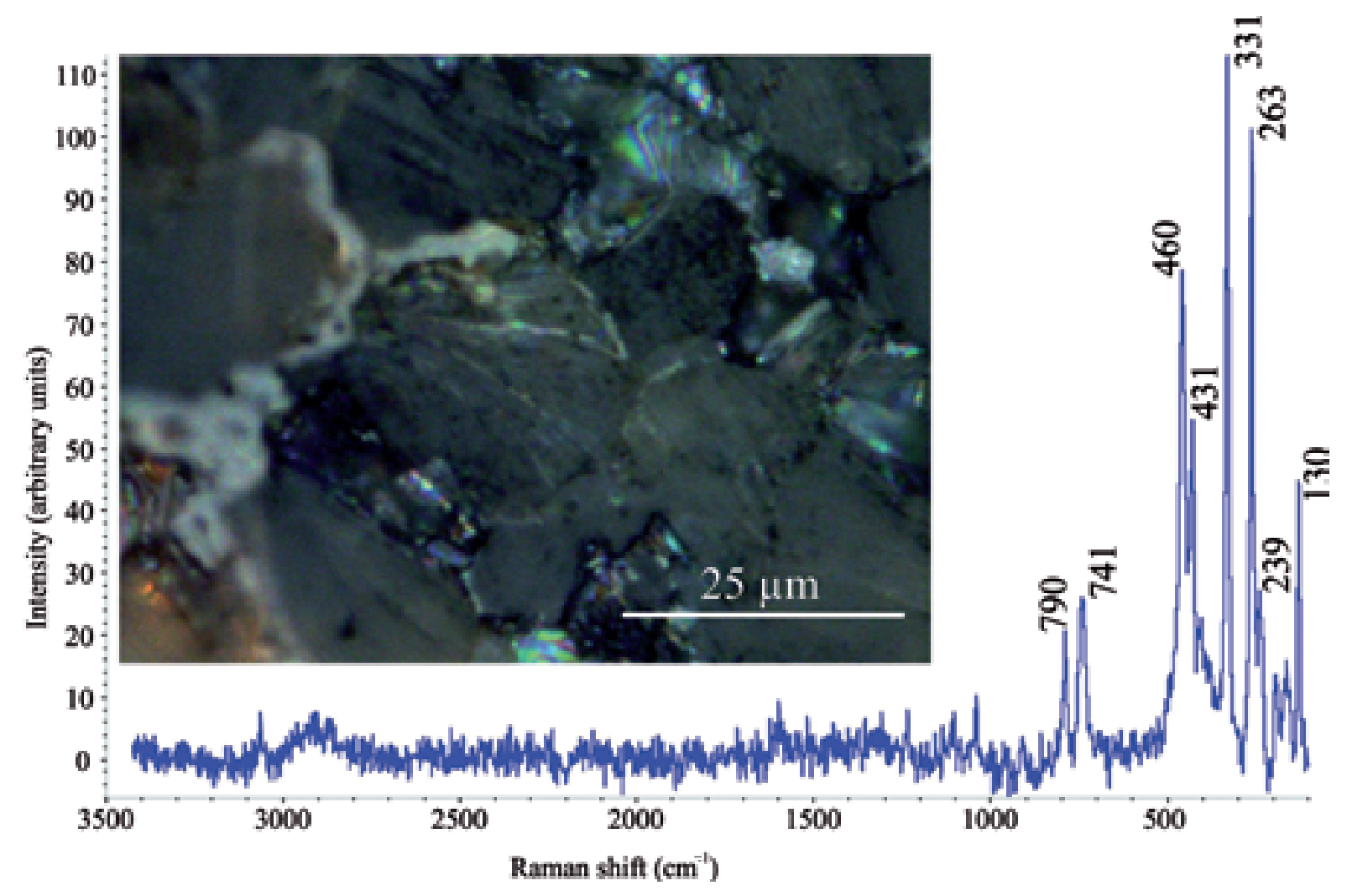

Fig. 7. Raman spectra of well-crystallized kaolinite (Naglik 2016)

Chlorite is one of the most common silicates in variety of geological environments occurring as a product of metamorphism as well as hydrothermal or diagenetic rocks alteration (Jiang et al. 1994). The relationship between chlorite chemical composition and physico-chemical conditions of its formation was observed by many authors (Cathelineau \& Nieva 1985, Walshe 1986, Kranidiotis \& McLean 1987, Cathelineau 1988, Vidal et al. 2001, 2005, 2006, Inoue 2009). A new model published by Bourdelle et al. (2013) is applicable for the chlorites formed at the wide range of temperatures $\left(50-350^{\circ} \mathrm{C}\right)$ and under pressure lower than 4 kbars. Those conditions cover most of the geological systems, therefore it was chosen in the studied case.

Chemical composition of chlorite get from electron microprobe technique (EPMA) is indicative for iron-rich member of the chlorite mineral family group. The content of main components $(\mathrm{Mg}, \mathrm{Fe}, \mathrm{Si}, \mathrm{Al})$ is similar independently whether the particles from vein or surrounding rock mass were analyzed. Some differences can be noticed when considering trace elements content: chlorite originating from rock mass bears higher amount of $\mathrm{Ti}$, which was released during mica transformation process. Temperatures obtained for chlorites from veins range from $141^{\circ} \mathrm{C}$ to $195^{\circ} \mathrm{C}$, while for chlorites from rock mass fluctuate from $102^{\circ} \mathrm{C}$ to $171^{\circ} \mathrm{C}$. Lower temperatures obtained for chlorite from rock mass should be explained by low heat conductivity of pelitic rock.

The time of calcite crystallization is unclear. As the euhedral crystals of this mineral are entrapped within quartz, it could be assumed that calcite was formed primary. Calcite does not show the presence of inclusions, what result from tectonic engagement of the crystals during their evolution history.

The temperatures of the thermal maturation of rocks were also determined on the basis of the Raman data of carbonaceous material. Raman spectra of carbonaceous material (CM) consist of two board bands in the range of $1000-1800 \mathrm{~cm}^{-1}$ (first order region) and $2500-3100 \mathrm{~cm}^{-1}$ (second order region). The shape of the Raman spectra of CM show systematic changes due to its crystallinity (Beyssac et al. 2002a, Rahl et al. 2005, Aoya et al. 2010, Lahfid et al. 2010), especially within the first order 
region where 4 or 5 bands can be distinguished: D1 $\left(\sim 1620 \mathrm{~cm}^{-1}\right)$, D2 $\left(\sim 1350 \mathrm{~cm}^{-1}\right)$, D3 $\left(\sim 1510 \mathrm{~cm}^{-1}\right)$, D4 $\left(\sim 1245 \mathrm{~cm}^{-1}\right), \mathrm{G}\left(\sim 1585 \mathrm{~cm}^{-1}\right)$. A model proposed by Kouketsu (2014) defines the relation between the full width at half maximum (FWHM) of D1-band and the temperature of $\mathrm{CM}$ alteration.

Carbonaceous material occurs in all rock types from the PMSF, where it is associated with the pyritic and goethite-coated bacterial cells. CM is also present in the dispersed form. As the goethite Raman spectra are composed of bands of the wave number close to those of the CM, the Kouketsu (2014) model could not be used in reference to the clayey shales. Therefore the temperatures were only calculated for the mudstones, where CM is connected with pyrite of framboidal and euhedral crystals. The observations were performed in reference to the CM from vein and from the surrounding rock mass. The temperature of $\mathrm{CM}$ alteration clearly decreases with the distance from the vein, implying the hydrothermal cause of host rock thermal maturation. The temperatures characterizing the $\mathrm{CM}$ from the vein exceeded $200^{\circ} \mathrm{C}$ (Fig. 8), while values calculated for $\mathrm{CM}$ from the surrounding rock mass rather fluctuate from $174^{\circ} \mathrm{C}$ to $195^{\circ} \mathrm{C}$. The temperatures do not differ whether CM from framboids or euhedral crystals was examined.

The presented paleothermal data corresponds to that which was previously published by Szczepanik (1997). According to that study, the rock complex of the Pepper Mts. was altered at temperatures ranging from $100^{\circ} \mathrm{C}$ to $200^{\circ} \mathrm{C}$ due to the presence of the heat flow zone although hydrothermal activity could also be considered as the cause of the heating, with hot fluids originating from the metamorphic basin. Nevertheless, the high temperatures characterizing the Pepper Mts. confirm their relationship to the Łysogóry unit (Szczepanik 1997).

\section{Products of weathering}

The rock complex of the Pepper Mts. has been exposed to both physical and chemical weathering, resulting in secondary mineral crystallization. The manner and character of the weathering cover depends on the host rock lithology (Naglik et al. 2016).

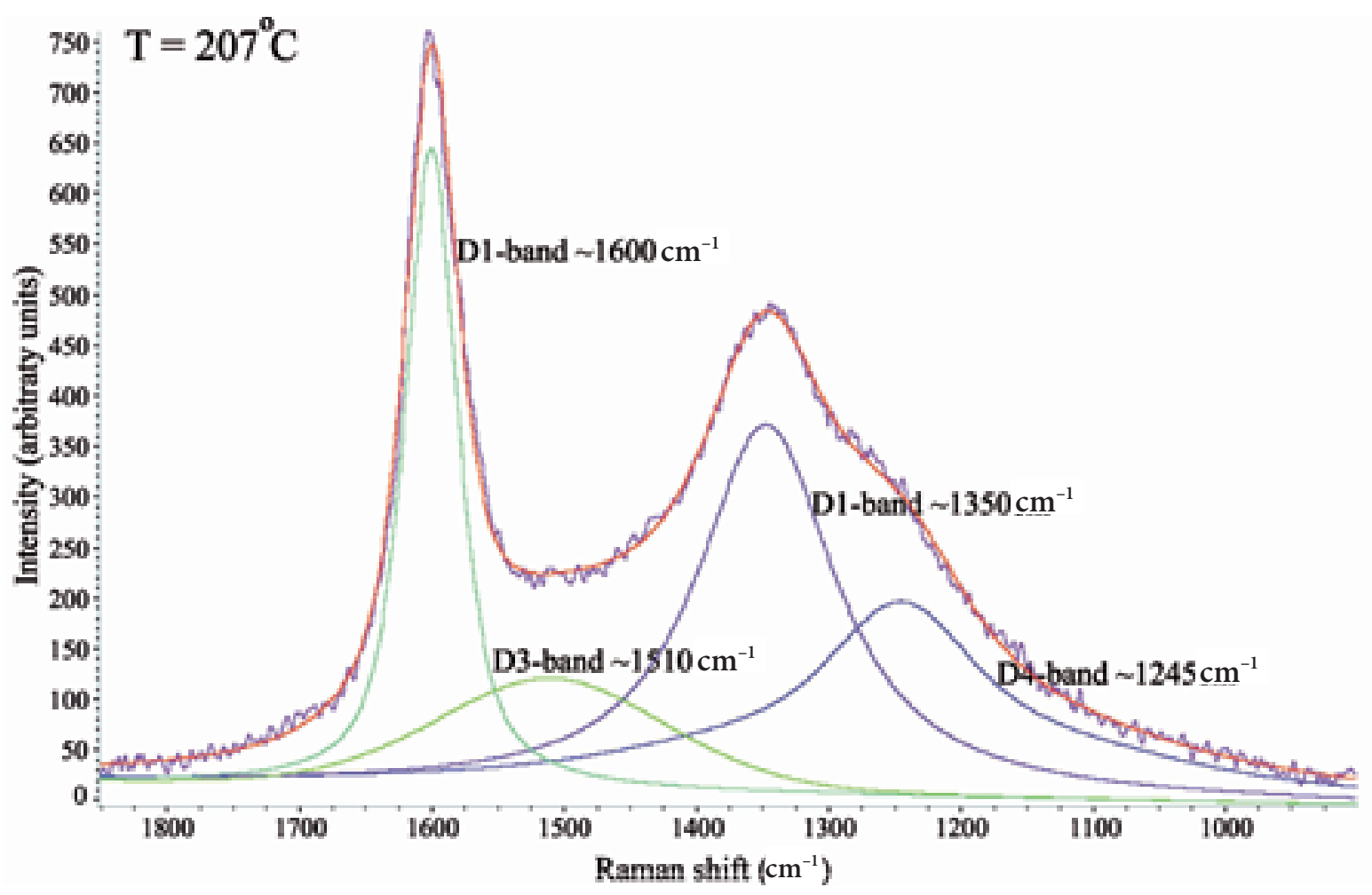

Fig. 8. Raman spectra of carbonaceous material with decomposition for five bands 
On the surface of the non-pyritic clayey shales, kaolinite is predestined to form. In the zone where pyrite-bearing mudstones occur, a sulphate association can be observed, firstly described as alum incrustations (Fig. 9).

Pickeringite is a highly hydrated sulphate mineral owing its origin to the oxidation of pyrite. The main factor controlling the pickeringite crystallization is also the $\mathrm{pH}$ of the environment. Pickeringite is a Mg-rich member of the halotrichite group with theoretical formula $\left[\mathrm{MgAl}_{2}(-\right.$ $\left.\mathrm{SO}_{4}\right)_{4} \cdot 22 \mathrm{H}_{2} \mathrm{O}$ ]. Chemically pure minerals from the halotrichite group are rare as most of the specimens form transitional phases between end members - the most common isomorphic substitution between pickeringite and halotrichite is observed (Parafiniuk 1991). XRD and chemical data of pickeringite from the Pepper Mts. indicates that the pickeringite in the studied case also occurs as transitional phase between pickeringite and halotrichite (Naglik \& Natkaniec-Nowak 2015, Naglik et al. 2016).

The Pepper Mts. fulfill all of the conditions required for pickeringite crystallization (Naglik \& Natkaniec-Nowak 2015, Naglik et al. 2016). The environmental enrichment in ions: $\mathrm{Al}^{3+}, \mathrm{Mg}^{2+}$ and $\mathrm{S}^{2-}$ is a result of transformation processes of minerals from the host rock. The co-occurrence of pickeringite, alunogen and epsomite could be explained by the changeable ion delivery during crystallization and the different solubility of those phases which determines their preservation.

Hydrated sulphates are highly soluble in water therefore the trace elements borne by their inner structure could easily be related during dissolution processes. Qualitative XRF examination shows the content of: $\mathrm{Zn}, \mathrm{Ni}$ and $\mathrm{Cu}$ in the studied sample. It may imply that heavy metals are easily absorbed by a pickeringite structure and can subsequently be transmitted to the environment.

Due to the presented results it can be assumed that the term of "alum shale" given to these rocks by Samsonowicz (1920) can no longer be used (Naglik et al. 2016). Thiss statement confirm the conclusion previously drawn by Przewłocki (2000).

\section{DISCUSSION AND CONCLUSIONS}

The evolution of the Pepper Mts. Shale Formation was reconstructed on the basis of mineralogical associations characterizing particular stages of its geological history.

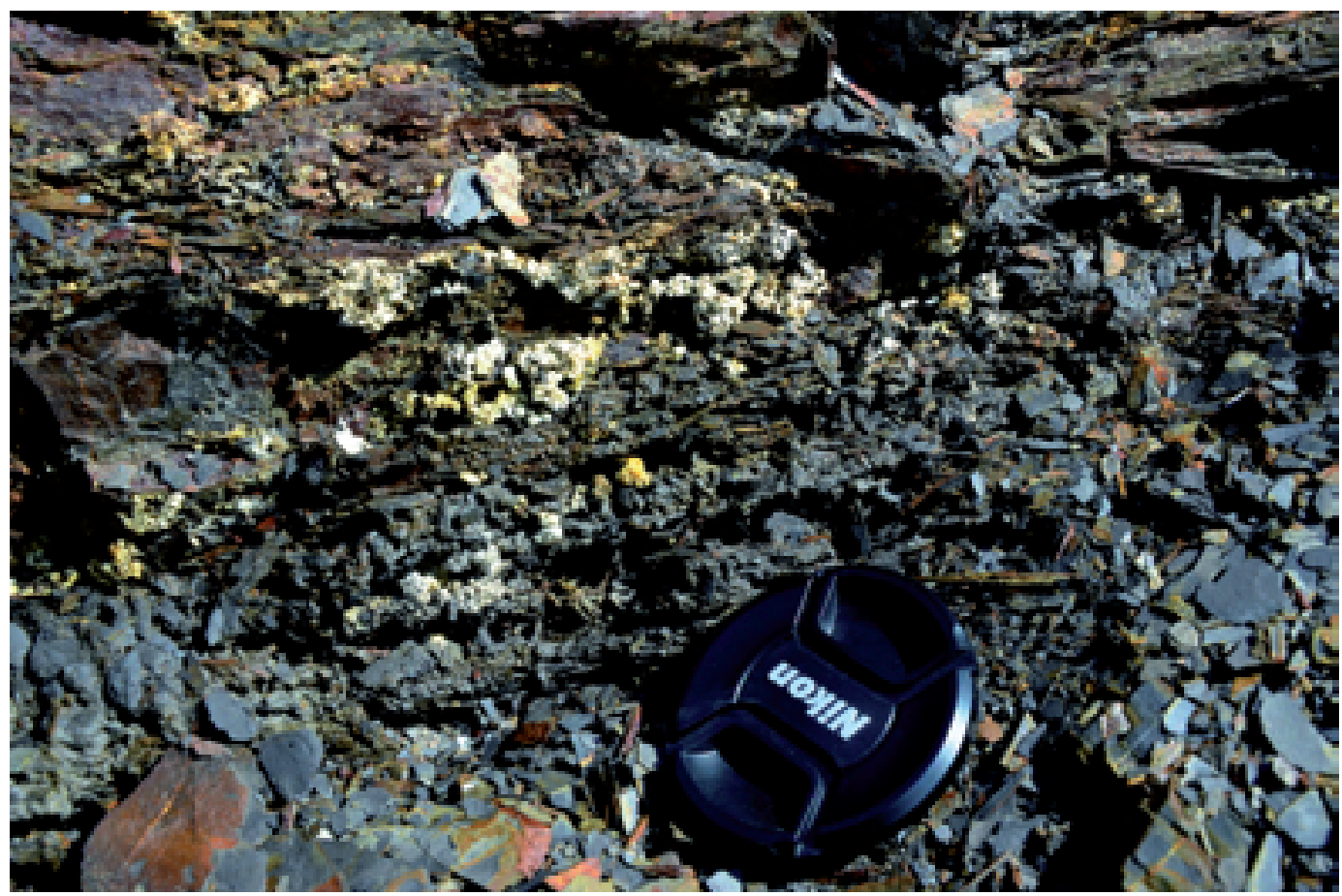

Fig. 9. Sulphate association occurring on the outcrops of pyrite-bearing rocks (Naglik 2016) 
Pyrite and goethite are interpreted as resulting from biomineralization processes during the sedimentary or early diagenetic stage. The manner of the co-existence of pyrite/goethite and carbonaceous material is symptomatic for the biological origin of that mineral. The subsequent thermal maturation of rocks is considered as resulting from hydrothermal fluid activity rather than from burial diagenesis as it was previously supposed. Hydrothermal activity caused changes in the mineral composition of the studied sediments. Probably the primary components of those clastic rocks were not diversified and consisted of: clay minerals (smectite, illite), terrigenous quartz, micas (muscovite, biotite) and heave minerals (zircon, anatase). The $\mathrm{pT}$ conditions of hydrothermal alteration were documented on the basis of quartz inclusion studies, chlorite geothermometry and the Raman data of carbonaceous material. Under hypergenic conditions, the rock complex was subjected to physical and chemical weathering and, due to these processes, the sulphate association mainly consists of pickeringite precipitate. It is the third known occurrence of this highly hydrated sulphate in Poland.

The results presented in this paper do not provide evidence for the role of regional metamorphism in the evolutionary history of the PMSF. Nevertheless, Salwa (2006) was the first to find phyllite outcrops in Kamecznica Podmąchocicka and this may indicate that rocks underwent alteration locally in the conditions characteristic for the greenschist zone. It is possible that phyllites also occur in the Pepper Mts. - stratotype area for the formation. If so, they can be interesting material for further study, giving us a new insight into the role of regional metamorphism in the Holy Cross Mts.

\section{Final remarks}

1. The mineral associations from Cambrian clayey shales, mudstones and sandstones provide an insight into the evolutionary history of the succession.

2. Pyrite and goethite of a biological origin could be formed in the early diagenetic or sedimentary stage.

3. Diagenetic alteration of the sediments is difficult to reconstruct as subsequent hydrothermal activity caused their mineralogical recomposition.

4. Quartz crystallized from hot fluids with temperatures which reached even $300^{\circ} \mathrm{C}$.

5. Kaolinite was formed in the younger episode of fluid discharge at an unknown temperature.

6. Goethite occurs as evidence of the youngest fluid activity. During this stage kaolinite recrystallized into chlorite. The temperature of this event, calculated due to the Bourdelle et al. (2013) model, reaches $195^{\circ} \mathrm{C}$.

7. Hydrothermal fluid circulation caused the maturation of carbonaceous material occurring both in veins and in surrounding rock mass. The temperatures calculated due to the Kouketsu et al. (2014) model exceed $200^{\circ} \mathrm{C}$ for $\mathrm{CM}$ from veins. Temperatures obtained in reference to particles from rock mass fluctuate from $174^{\circ} \mathrm{C}$ to $195^{\circ} \mathrm{C}$.

8. Temperatures obtained on the basis of quartz inclusion study, chlorite geothermometry and organic matter Raman data correlate one another. It means that the mathematical models proposed by Bourdelle et al. (2013) and Kouketsu et al. (2014) give reliable results in the low temperature hydrothermal system.

9. The presented results correspond to data previously obtained by Szczepanik (1997). The relationship of the Pepper Mts. with Łysogóry Unit was therefore confirmed.

10. Under hypergenic conditions, sulphate association occurs within the pyrite-bearing rocks outcrops. The main component of the white crust is pickeringite and therefore the term of "alum shales" cannot still be used, as previously noticed by Przewłocki (2000).

11. The mineral composition of the rocks from the PMSF is not diversified but every mineral component delivers important information about evolution history of the succession, even in regional aspects. Further studies are required as some of the genetic problems still await explanation - especially connected with the regional metamorphism.

The presented results and remarks summarize a Ph.D. dissertation by $B$. Naglik. The reviewers are warmly thanked for their suggestions of improvements to this manuscript. Paweł Wróbel (AGH UST, Poland), 
Tomas Mikus (SAV, Slovakia), Marta Bak (AGH UST, Poland), Tomasz Toboła (AGH UST, Poland) are thanked for the help with analytical works. Authors are also thankful to Sylwester Salwa (PIG-PIB, Poland) for valuable comments during research.

The work was supported by the AGH University of Science and Technology project No. 11.11.140.319 and 15.11.140.642.

\section{REFERENCES}

Aoya M., Kouketsu Y., Endo S., Shimizu H., Mizukami T., Nakamura D. \& Wallis S., 2010. Extending the applicability of the Raman carbonaceous-material geothermometer using data from contact metamorphic rocks. Journal of Metamorphic Geology, 28, 895-914.

Bąk M., Naglik B., Natkaniec-Nowak L., Bąk K., Dulemba P., 2015. New record of organic-walled microfossils from the Middle Cambrian deposits of the Pieprzowe Mts, Poland. [in:] VIET-POL 2015: second international conference on Scientific research cooperation between Vietnam and Poland in earth sciences: Hanoi, Vietnam, 5-6 November 2015, Bach Khoa Publishing House, Vietnam, 93-96.

Beyssac O., Goffé B., Chopin C. \& Rouzaud J. N., 2002. Raman spectra of carbonaceous material in metasediments: a new geothermometer. Journal of Metamorphic Geology, 20, 859-871.

Bielecka M., 1964. Objaśnienia do Szczegółowej mapy geologicznej Polski w skali 1:50 000; arkusz Zawichost. Wydawnictwa Geologiczne, Warszawa.

Bourdelle F., Parra T., Chopin Ch. \& Beyssac O., 2013. A new chlorite geothermometer for diagenetic to low-grade metamorphic conditions. Contributions to Mineralogy and Petrology, 165, 723-735.

Burke E.A.J., 2001. Raman microspectrometry of fluid inclusions. Lithos, 55, 1, 139-158.

Cathelineau M. \& Nieva D., 1985. A chlorite solid solution geothermometer, The Los Azufres (Mexico) geothermal system. Contributions to Mineralogy and Petrology, 91, $3,235-244$.

Cathelineau M., 1988. Cation site occupancy in chlorites and illites as a function of temperature. Clay Minerals, 23, 4, 471-485.

Gürich G., 1892a. Über eine cambrische Fauna von Sandomir in Russisch-Polen. Neues Jahrbuch für Mineralogie, 1, 1, 69-70.

Gürich G., 1892b. Über eine Trilobiten-Fauna bei Sandomir. Jahres-Bericht der Schlesischen Gesellschaft für Vaterländische Cultur, 55.

Gürich G., 1899-1901. Nachträge zum Paleozoicum in polnischen Mittelgebirge. Neues Jahrbuch für Mineralogie, $13,331-388$.

Inoue A., Meunier A., Patrier-Mas P., Rigault C., Beaufort D. \& Vieillard P., 2009. Application of chemical geothermometry to low-temperature trioctahedral chlorites. Clays and Clay Minerals, 57, 3, 371-382.

Jaworowski K. \& Sikorska M., 2010. Łysogóry Unit (Central Poland) versus East European Craton - application of sedimentological data from Cambrian siliciclastic association. Geological Quarterly, 50, 1, 77-88.

Jiang W.T., Peacor D.R. \& Buseck P.R., 1994. Chlorite geothermometry? - contamination and apparent octahedral vacancies. Clays and Clay Minerals, 42, 5, 593-605.

Kouketsu Y., Mizukami T., Mori H., Endo S., Aoya M., Hara H., Nakamura D. \& Wallis S., 2014. A new approach to develop the Raman carbonaceous material geothermometer for low-grade metamorphism using peak width. Island Arc, 23, 33-50.

Kowalczewski Z., 1995. Fundamental stratigraphic problem of the Cambrian in the Holy Cross Mts. Geological Quarterly, 39, 4, 449-470.

Kranidiotis P. \& Mclean W.H., 1987. Systematics of chlorite alteration at the Phelps Dodge massive sulfide deposit, Matagami, Quebec. Economic Geology, 82, 7, 1898-1911.

Kuhl J., 1931. Sprawozdanie z badań petrograficznych nad utworami środkowokambryjskimi Gór Pieprzowych koło Sandomierza. Posiedzenia Naukowe Państwowego Instytutu Geologicznego, 23, 24-26.

Lahfid A., Beyssac O., Deville E., Negro F., Chopin C. \& Goffé B., 2010. Evolution of the Raman spectrum of carbonaceous material in low-grade metasediments of the Glarus Alps (Switzerland). Terra Nova, 22, 5, 354-360.

Malec J., 2006. Sekwencja utworów chaotycznych kambru z Gór Pieprzowych. Posiedzenia Naukowe Państwowego Instytutu Geologicznego, 63, 75-76.

Mastella L. \& Mizerski W., 1981. Etapy deformacji tektonicznych utworów kambru środkowego Gór Pieprzowych. Przegląd Geologiczny, 29, 7, 351-355.

Michniak R., 1969. Petrografia ryfeju i kambru wschodniej części Gór Świętokrzyskich. Studia Geologica Polonica, 30, 1-106.

Naglik B., 2016. Badania mineralogiczno-petrograficzne utworów skalnych z Gór Pieprzowych (Wyżyna Sandomierska), ze szczególnym uwzględnieniem produktów ich przeobrażeń. Akademia Górniczo-Hutnicza, Kraków [Ph.D. thesis, unpublished].

Naglik B., Heflik W. \& Natkaniec-Nowak L., 2016. Charakterystyka mineralogiczno-petrograficzna utworów klastycznych Gór Pieprzowych (Wyżyna Sandomierska) i produktów ich wietrzenia. Przegląd Geologiczny, 64, 5, 338-343.

Naglik B. \& Natkaniec-Nowak L., 2015. Pickeringite from the Pieprzowe Mts. (the Holy Cross Mts., Central Poland). Geology, Geophysics \& Environment, 41, 1, 114-115.

Naglik B., Toboła T. \& Natkaniec-Nowak L., 2015. Inclusions in authigenic quartz from the Pepper Mts. Shale Formation - a Raman microspectroscopic study. Mineralogia Polonica-Special Papers, 44, 76.

Orłowski S., 1964. Kambr środkowy i jego fauna we wschodniej cz. Gór Świętokrzyskich. Studia Geologica Polonica, $16,1-94$.

Orłowski S., 1975. Jednostki litostratygraficzne kambru i górnego prekambru Gór Świętokrzyskich. Acta Geologica Polonica, 25, 431-448.

Parafiniuk J., 1991. Fibroferrite, slavikite and pickeringite from the oxidation zone pyrite-bearing schists in Wieściszowice (Lower Silesia). Mineralogia Polonica, 22, 1, 3-13.

Przewłocki Z., 2000. Środowisko depozycji kambryjskiej formacji łupków z Gór Pieprzowych, Góry Świętokrzyskie. Uniwersytet Warszawski, Warszawa [Ph.D. thesis, unpublished]. 
Push G.G., 1833. Geognostische Beschreibung von Polen so wie der ubringen Nordkarpathen-Lander. Bd, 1, Stuttgart.

Rahl J.M., Anderson K.M., Brandon M.T. \& Fassoulas C., 2005. Raman spectroscopic carbonaceous material thermometry of low-grade metamorphic rocks: Calibration and application to tectonic exhumation in Crete, Greece. Earth and Planetary Science Letters, 240, 2, 339-354.

Roedder E., 1984. Fluid Inclusions: An Introduction to Studies of All Types of Fluid Inclusions, Gas, Liquid, or Melt, Trapped in Materials from Earth and Space, and Their Application to the Understanding of Geologic Processes. Reviews in Mineralogy, 12, Mineralogical Society of America, Washington.

Salwa S., 2006. Wstępna charakterystyka strukturalno-petrograficzna fyllitów z Podmąchocic w regionie łysogórskim Gór Świętokrzyskich. Przegląd Geologiczny, 54, $6,513-520$.

Samsonowicz J., 1916. Materiały do geologii Gór Świętokrzyskich. Kambr i kambro-sylur Gór Świętokrzyskich. Sprawozdania z Posiedzeń Towarzystwa Naukowego Warszawskiego. Wydział III Nauk Matematycznych i Przyrodniczych, 9, 4, Warszawa, 321-351.

Samsonowicz J., 1920. O stratygrafii kambru i ordowiku we wschodniej części Gór Świętokrzyskich. Sprawozdania Państwowego Instytutu Geologicznego, 1, 1, Warszawa.

Siemiradzki J., 1886. Studien im polnischen Mittelgebirge. Kaiserlich-Königlichen Geologischen Reichsanstalt, 36, 3, 671-672.

Siemiradzki J., 1887. Sprawozdanie z badań geologicznych we wschodniej części Gór Kielecko-Sandomierskich. Pamiętnik Fizjograficzny, 7, 11-37.

Szczepanik Z., 1997. Preliminary results of thermal alteration investigations of the Cambrian acritarchs in the Holy Cross Mts. Geological Quarterly, 41, 3, 257-264.

Środoń J., 1996. Minerały ilaste $\mathrm{w}$ procesach diagenezy. Przegląd Geologiczny, 44, 6.
Tietze E., 1883a. Die Geged nordlich von Rzeszów in Galizien. Verhandlungen der Kaiserlich-Königlichen Geologischen Reichsanstalt, 2, 31.

Tietze E., 1883b. Beitrege zur Geologie von Galizien. A. Das Hugelland und die Ebene bei Rzeszów. Kaiserlich-Königlichen Geologischen Reichsanstalt, 33, 300-302.

Vidal O., Parra T. \& Trotet F., 2001. A thermodynamic model for Fe-Mg alumonous chlorite using data from phase equilibrium experiments and natural pelitic assembalges in the $100^{\circ}-600^{\circ} \mathrm{C}, 1-25 \mathrm{~kb}$ range. American Journal of Science, 301, 6, 557-592.

Vidal O., Parra T. \& Vieillard P., 2005. Thermodynamic properties of the Tschermak solid solution in Fe-chlorite: application to naturale examples and possible role of oxidation. American Mineralogist, 90, 2-3, 347-358.

Vidal O., De Andrade V., Lewin E., Munoz M., Parra T. \& Pascarelli S., 2006. P-T deformation- $\mathrm{Fe}^{3+} / \mathrm{Fe}^{2+}$ mapping at the thin section scale and comparison with XANES mapping: application to a garnet-bearing metapelite from the Sambagawa metamorphic belt (Japan). Journal of Metamorphic Geology, 24, 7, 669-683.

Walshe J.L., 1986. A six-component chlorite solid solution model and the conditions of chlorite formation in hydrothermal and geothermal systems. Economic Geology, 81, 681-703.

Wilkin R,T. \& Barnes H.L., 1996. Pyrite formation by reactions of iron monosulfide with dissolved inorganic and organic sulfur species. Geochimica et Cosmochimica Acta, 60, 21, 4167-4179.

Zejszner L., 1869. Über die neuntdeckie Silurformation von Kleczanów hei Sandomir im südlichen Polen. Zeitschrift der Deutschen Geologischen Gesellschaft, 21, 569-573.

Żak C., 1962. Wstępne stadium tektoniczne środkowego kambru Gór Pieprzowych. Biuletyn Instytutu Geologicznego, 174, 5, 9-49. 